\title{
The Performance of Saudi Banking Industry 2000 -2011: Have the Banks Distinguished Themselves from One Another?
}

\author{
Bukhari M. S. Sillah ${ }^{1}$, Imran khokhar $^{1} \&$ Muhammad Nauman $\operatorname{Khan}^{2}$ \\ ${ }^{1}$ Department of Economics, College of Business Administration, King Saud University, Riyadh, Saudi Arabia \\ ${ }^{2}$ Department of Finance, College of Business Administration, King Saud University, Riyadh, Saudi Arabia \\ Correspondence: Bukhari M. S. Sillah, Assistant Professor, Department of Economics, College of Business \\ Administration, King Saud University, Riyadh, Saudi Arabia. E-mail: bsillah73@yahoo.com
}

Received: March 4, 2014

Accepted: March 19, 2014

Online Published: April 1, 2014

doi:10.5430/ijfr.v5n2p121

URL: http://dx.doi.org/10.5430/ijfr.v5n2p121

\begin{abstract}
This paper studies the technical efficiency of Saudi banking sector using stochastic frontier model. A sample of 12 banks over the period 2000 - 2011 is selected to investigate their technical efficiencies in mobilizing deposits, allocating investments and generating income. The banks are categorized as Saudi-owned banks, Saudi - foreign owned banks and Islamic banks. The findings show some consistent pattern of these bank types; and there exist significant disparities among the banks in terms of technical efficiency. The banque Saudi Fransi stands out as a benchmark for the industry, and it is a Saudi -foreign owned bank type. The Saudi owned bank type has shown fluctuating performance during the period; and the Islamic bank type is not significantly different from Saudi-owned bank type.
\end{abstract}

Keywords: technical efficiency, stochastic frontier analysis, bank type

\section{Contributions and implications of the paper:}

- The paper appears to be the second of its kind, after Alkhathlan et al (2010) to study the technical efficiency of Saudi banks.

- The paper distinguishes itself from the previous work of Alkhathlan et al (2010) by adding the dimensions of philosophical foundations and ownership structures of the banks in the analysis. It also expands the analysis by looking at three output variables instead of one output variable.

- The paper tends to raises a further research question concerning the relationship between the bank performance and its ownership structure and philosophical foundation. Though, the current paper tends to suggest that there exists a relationship between the two; further researches with different samples from Saudi market and around the world are suggested to test this relationship.

\section{Limitation:}

- The paper does not have labour data to use as an input variable; instead it employs an administrative expense as a proxy for the labour input.

\section{Introduction}

This paper investigates the performance of the Saudi banking industry, which consist of Saudi-owned, Saudi-foreign-owned and Islamic banks. From its capital and labour, the banking industry mobilizes deposits, and create loan, and generate income. In this process, the industry faces two major efficiency issues which are input efficiency and output efficiency. Holding the output constant and comparing the inputs across banks produces the input efficiency measure. The output efficiency is obtained by holding the input constant and comparing the outputs across the banks. Each of the two measures generates the overall technical efficiency measure. Saudi banking industry is highly liquid and rich in financial resources, and it has so far weathered off the recent world financial crises. This raises three major questions for research and investigation: For example, has the Saudi banking industry become a natural monopoly due to its intertwined structural ownership? The industry has very limited foreign ownership, and majority of its players are holding ownerships in one another. This ownership structure could enable it to realize decreasing average total costs, and hence economies of scale. The second question also relates to the ownership structure but in times of Saudi-owned and Saudi-foreign owned structures. Does this nature of structural 
ownership provide information about the efficiency within the industry? The third question concerns the parallel functioning of both conventional and Islamic banks, and have the two systems been distinctly different from each other over time in terms of technical efficiency. This paper attempts to answer the last two questions, as the first question is beyond the scope of this study. It analyses the technical efficiency of the banks over the time period 2000 2011, and in comparison to one another as bank type is concerned. The paper employs the stochastic production frontier model to answer the above questions. The rest of the paper is organised as background review, literature review, methods, analysis and conclusions and implications.

\subsection{Background Review}

Banking sector of Saudi Arabia is one of the world's stable and fastest growing banking markets. In the last decade, Saudi banking industry has witnessed visible improvements in organizational structure, size, financial health, outreach and utilization of technology. Banks operating in the country have to face competitive environment as new foreign banks are commencing their operation. Saudi economy is heavily dependent on hydrocarbon sector, so it has performed well as oil prices increased in the international market in last few years. With high liquidity level and oil sector driven profits in last years, banking industry performed well and recorded its good growth in assets and deposits. Even in the mid of world financial crisis, Saudi banking industry showed impressive growth results and expanded lending activities even at the time when there were adverse economic conditions all around the world.

Currently Saudi banking industry has 23 commercial banks, of which 12 domestic banks and 11 foreign banks have their branches in the kingdom. In 2004, SAMA made some amendments in the regulation and allowed foreign banks to operate in the kingdom. As a result foreign banks started opening their branches in the country and that created a healthy competition within the industry. From the 12 domestic banks, 8 banks are totally Saudi-owned and four are joint ventures with foreign international banks. In the domestic commercial banks, 4 banks are full-fledged Islamic banks, while the other banks offer both Islamic and interest based products under one umbrella. The commercial banks operate more than 1,600 branches throughout the country and a widespread network of automated teller machines. Beyond providing credit and deposit facilities, they engage in securities trading, investment banking, foreign exchange services, government finance, and development of a secondary government bond-treasury bill market. In this section, we examine the bank density of the industry, its services growth in terms of teller machines and its competition in terms of the major players in the industry.

Bank density, as shown in Table 1 below, means how many branches are served to each 100,000 people. In Saudi Arabia the bank density is relatively low as compare to developed countries. In Saudi Arabia 6.07 branches are served for every 100,000 population in 2011 ; it increased by $6.49 \%$ from what it was in 2006 . In 2005 , United States had 31 branches for 100,000 people; and in Hungary bank density was 28 branches. In the Arab world, for example in Egypt bank density was 4 branches (Economist, 2005).

Table 1. Bank density in Saudi Arabia

\begin{tabular}{lcc}
\hline City & Bank Density 2006 & Bank Density 2011 \\
\hline Riyadh & 6.9 & 7.27 \\
\hline Makkah & 5.2 & 5.38 \\
\hline Al-Madinah & 4.2 & 4.22 \\
\hline Eastern & 6.4 & 7.53 \\
\hline Al-Qassim & 8.0 & 8.55 \\
\hline Asir & 4.9 & 5.33 \\
\hline Tabouk & 4.5 & 5.05 \\
\hline Hail & 4.9 & 5.36 \\
\hline Northern Borde & 4.6 & 4.37 \\
\hline Al-Jawf & 4.7 & 4.55 \\
\hline Jazan & 2.5 & 2.71 \\
\hline Najran & 4.3 & 4.35 \\
\hline Al-Bahah & 5.6 & 6.31 \\
\hline Total & 5.7 & 6.07 \\
\hline
\end{tabular}

Source: Authors calculation based on Annual Report SAMA 2012 \& Central Department of Statistics, KSA 2012 
Bank density has increased in Saudi Arabia in some previous years as some new banks start operation in market and the existing banks expand their branch network, but it was a modest increase. The highest bank density was in Al-Qassim region with 8.55 branches, and the lowest was in Jazan region with 2.71 branches. That is, the bank density appears to follow the economic activity in the country. Al-Qassim enjoys high economic activity due to the concentration of oil and oil related activities, whereas Jazan region is of relatively smaller economic activity compared to other regions. The bank density has seen a big jump in the country probably due to two factors. One factor is the increased influx of foreign labour into the country, and this definitely increased the population, and in turn it would cancel out some increases in the bank branch. The other factor is the increased reliance of Saudi banks on machine, electronic systems and telephones to offer their services.

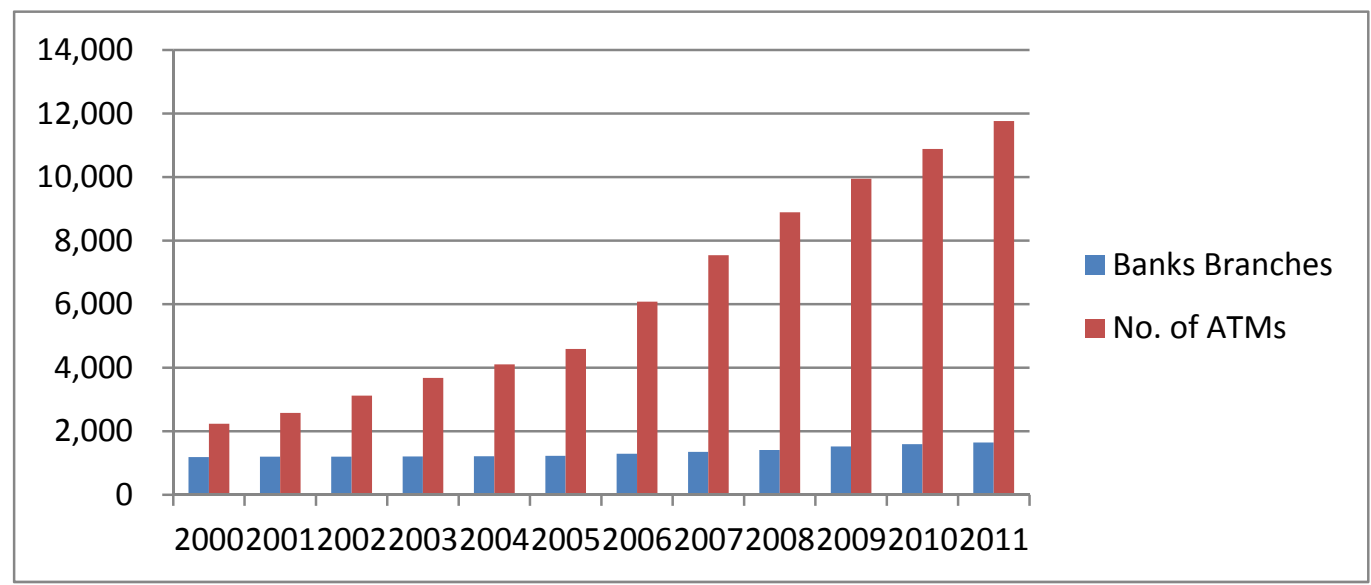

Figure 1. ATMs and banks' branches growth in Saudi Arabia

As the figure above illustrates, the automatic teller machines (ATMs) have kept rapidly increasing. Banks establish wide ATM networks that provide almost all banking services of deposit, withdrawal and transfer of funds. Through these ATMs, payment of all household bills like telephone, electricity, mobile, etc. and payment for all government services can be done. Due to increasing cost (particularly labor cost) of establishing a new branch, often opt for installing an ATM with all teller functions than to operate a branch. In 2007, Government started to transfer salaries of employees into their bank accounts, forcing more people to use banking services. The super markets are accepting ATM, Debit or Credit cards, and this too increases the clientele of banks. But still as compare to developed countries, less portion of the population is using banking services due to some social, cultural and religious constraints.

Table 2. Major banking sector players in Saudi Arabia

\begin{tabular}{lccc}
\hline \multirow{2}{*}{ Bank Name } & Total Assets & Loans & Deposits \\
& & & \\
\hline Riyad Bank - RIBL & $11.71 \%$ & $13.19 \%$ & $11.67 \%$ \\
\hline Bank Al Jazira - BJAZ & $2.52 \%$ & $2.72 \%$ & $2.82 \%$ \\
\hline The Saudi Investment Bank - SIBC & $3.36 \%$ & $3.17 \%$ & $3.33 \%$ \\
\hline Saudi Hollandi Bank - AAAL & $3.73 \%$ & $4.41 \%$ & $4.08 \%$ \\
\hline Banque Saudi Fransi - BSFR & $9.10 \%$ & $10.78 \%$ & $9.96 \%$ \\
\hline SABB - SABB & $8.98 \%$ & $9.90 \%$ & $9.57 \%$ \\
\hline Arab National Bank - ARNB & $7.61 \%$ & $8.50 \%$ & $7.96 \%$ \\
\hline Samba Financial Group - SAMBA & $12.48 \%$ & $10.40 \%$ & $11.44 \%$ \\
\hline Al Rajhi Bank - RJHI & $14.30 \%$ & $16.39 \%$ & $14.71 \%$ \\
\hline Bank Al Bilad - ALBILAD & $1.80 \%$ & $1.61 \%$ & $2.09 \%$ \\
\hline Alinma Bank - ALINMA & $2.38 \%$ & $2.95 \%$ & $1.61 \%$ \\
\hline The National Commercial Bank - NCB & $19.50 \%$ & $15.79 \%$ & $19.70 \%$ \\
\hline Total & $97.47 \%$ & $99.80 \%$ & $98.94 \%$ \\
\hline
\end{tabular}

Source: Authors calculation based on Annual Report SAMA 2012 
This pare will focus on measuring the efficiency of overall Saudi Arabian banking sector represented by 12 banks, whose total assets constitute $97.47 \%$ of total assets of the industry, and their total loans measure $99.80 \%$ of total loans of the industry; and they possess $98.94 \%$ of the deposits of banking industry. The 12 banks, selected for the study, own more than $99 \%$ of branches country wide.

\section{Literature Review}

There are generally two methods to examine the banking efficiency. Data Envelopment Analysis is one method that allows for multiple outputs and multiple inputs. It can decompose the overall efficiency into scale and pure efficiency. The other advantage of DEA is the absence of need to make an assumption about the distribution of variables on the study. The other method of efficiency study employs a parametric production function that study the relationship between single outputs and one or more inputs. It assumes that the variable conform normally distributed population. Both methods have been employed in studying the banking performance such as the stories of Rosly and Abu Baker (2003), Drake and Hall (2003), Sufian (2007), Wu et al (2008) and recently Ali Said (2012).

The banking efficiency study has generally been concerned with three issues which are comparative study of efficiency, event study of efficiency and decomposition of efficiency. Comparative studies compares state and non-state/private owned banks, large and small banks, domestic and foreign banks, Islamic and non-Islamic banks, and international comparisons.

Frimpong (2010) conducts comparative study of efficiency across domestic private banks, state bank, and foreign banks in Ghana. He finds that domestic private banks top the list followed by foreign banks. Comparing domestic banks with foreign banks, Matousek and Taci (2004) find that the foreign banks have an edge over their domestic counterparts in Czech Republic. Thus, it was recommended to open up the domestic banking industry for foreign banks to boost the competition and efficiency in the banking industry. Comparing large banks with small banks, Wu et al (2008) conclude that large-sized banks are more efficient than the small-sized banks, the large-sized banks benefit from scale effects, and hence derive increasing returns to scale. This was earlier conformed in the study of Rosly and Abu Baker (2003), Matousek and Taci (2004), and recently by Zreika and Elkanj (2011). These finding does not hold for Japanese banking industry, where small-niche forecasted banks are more efficient and enjoy significant economies of scale than large-sized banks, Drake and Hall (2003). Comparing Islamic banks and conventional banks Rosly and Abubaker (2003) find the Islamic banks less efficient than the conventional banks due to large scale effect enjoyed by the conventional banks. But this cannot be robust reason as evidenced in the case of japan where small-sized banks fare better the large-sized ones. Mokhtar et al (2008) have reached similar conclusion that Islamic bank are less efficient But Shadi (2010) and Akhter et al (2011) find no significant difference between the types of banks. For international comparison, Maudo and pastor (1999) find that European and American banks better performance as cost and profit efficiencies are concerned, and hence European and Americans banks are generally more profitable than the Japanese counterparts due to the presence of efficiency inequalities between them in the Japanese banks. Comparing the domestic Islamic banks with the foreign Islamic banks, Mokhtar et al (2008) and Abdul Hadi and Saad (2010) find that domestic Islamic banks perform well than foreign Islamic banks. Thus, no consistent evidence for efficiency edges of foreign banks over domestic banks and of Islamic Banks over conventional banks. It could depend on stages of the economic and banking development of a country. For example, for Czech Republic transitioning from command economy to market economy foreign banks are expected to perform more efficiently than the domestic banks. But for highly developed Islamic Banking industry of Malaysia, domestic Islamic banks are expected to fare better in efficiency than the foreign Islamic banks. Similarly from a well-developed market economy domestic banks can perform more efficiently than foreign banks due to experience and market niche advantage for the domestic banks.

Event studies of efficiency are generally concerned with analysing banking efficiency over time or as some event, such as financial crises and level of competition, change. Maudo and Pastor (1999) find that is level of competition increases, European banks and American banks gain more in profit efficiency than their Japanese counterparts increased competition by allowing more banks into the industry, improves the performance and overall efficiency of the industry, Matousek and Taci (2004) event of financial crises impacts less on the efficiency and performance of Islamic Banks than that of conventional banks. Abdul Hadi and Saad (2010) Said (2012a) and Said (2012b). Studying the determinants of bank efficiency in a sample of banks in China, Mathews and Zhang (2010) find that cost reduction and technical diversification of revenue away from interest earnings are significant contributors to improving bank efficiency. The environments in which the banks operate are also important factors of bank efficiency as highlighted by Chortareas el at (2012). They find that banks operating in freer economic and political environments gain better cost advantages and overall efficiency than their counterparts in less free economic political 
environments. Analysing bank efficiency across eight Asian countries, Sun and Chang (20101) conclude that risk measures, such as credit risk, operational risk and market risk, are significant determinants of the variations in the level and variability of bank efficiency; and the results tend to be different across the countries and over time. Instead of asking what explain efficiency, Avkiran (2010) asks inversely: what does efficiency explain? And he finds that efficiency does explain significant variations in ratio of post-tax profit/ average total assets, and ratio of returns on average equity. It implies that if a firm is efficient, it should expect its profitability ratios to improve.

For the decomposition of efficiency, studies find that scale rather than pure efficiency dominate the overall efficiency of banks, Rosly and Abu Baker (2003), Sufian (2007) and Abdul Hadi and Saad (2010). But Baroos el at (2011) finds no influence of firm size on the efficiency. For the Saudi market Alkhathlan et al (2010) conducts a relative efficiency study of the industry and they find that it is players are generally efficient, and that ARB and BSF top the frontiers of the efficient performance with NCB as the least efficient. Investigating the efficiency of Middle East and North African (MENA) banks, Olson and Zoubi (2011) find that the MENA banks are less efficient than the European banks, and that they are par with the most banks of the developing economies.

The current paper on the Saudi banking industry pushes the investigation further by conducting both comparative and event studies. Specifically it undertakes to,

- Conduct comparative study of efficiency; Saudi-owned versus Saudi-foreign banks and Islamic banks versus conventional banks.

- Conduct the event study by analysing changes in the efficiency of banks over time 2000 to 2011 and how the financial crisis of 2008 impacts on the efficiency/performance of the industry and its players.

\section{Method and Data}

Efficiency of a firm can be decomposed into technical efficiency and allocative efficiency. Technical efficiency measure the capacity of the firm in maximizing output given the input or in minimizing the input given the output. The allocative efficiency measure the capacity of the firm in sufficiently choosing the input amount in light of their relative prices. This paper investigates the technical efficiency of the banks, as the paper is constrained by data limitations concern in the bank input prices to investigate the alloccative efficiency. The technical efficiency can be analysed through input-oriented efficiency measures or output-oriented efficiency measure within the context of constant returns to scale or variable returns to scale. If input are increased by certain percentage and the output increases by the same percentage, the firm faces constant return to scale (CRS); it faces variable return to scale (VRS) when the output increases by variable percentages. Under the constant return to scale, the production function exhibits a constant slope, and under variable return to scale, the production function exhibits a variable slope. Following model construction of Xuan Huy (2010), if a firm produces one output, Q, using one input, X, the production function frontier under CRS and VRS can be graphed as below:

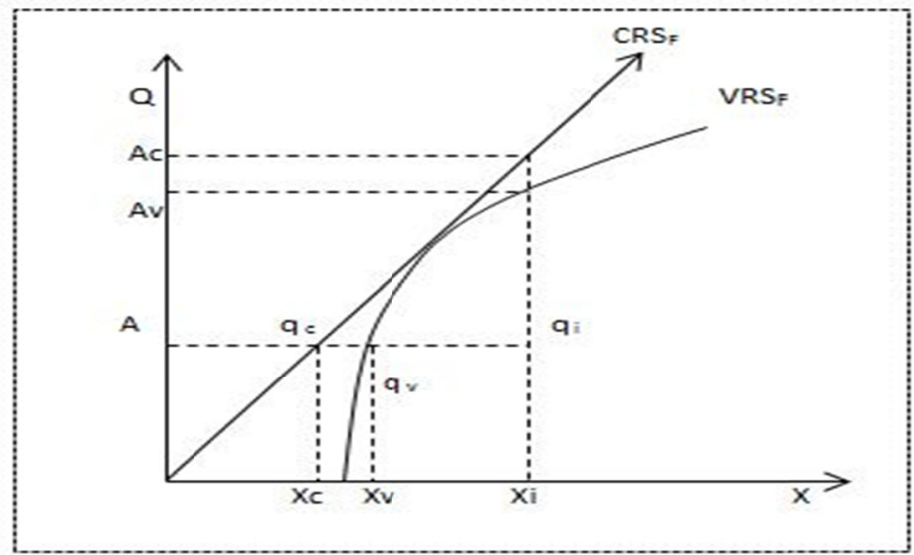

Figure 2. Production possibility frontier

Source: Xuan Huy (2010)

qi $=$ Inefficient Point of output

Technical inefficiency ratio under $\mathrm{CRS}=\mathrm{Aq}_{\mathrm{c}} / \mathrm{Aq}_{\mathrm{i}}[0,1]$

Technical inefficiency ratio under VRS $=\mathrm{Aq}_{\mathrm{v}} / \mathrm{Aq}_{\mathrm{i}}[0,1]$ 
The technical inefficiency scores are decomposed into pure technical inefficiency and scale technical inefficiency. The pure technical inefficiency measures inefficient management and leadership of the firm; whereas, scale technical inefficiency measures the technology used to transform the input into output and the size of the firm. The difference between the technical efficiency under constant return to scale and the technical efficiency and variable return to scale is the scale inefficiency. Thus, the scale inefficiency ratio from the graph above is measured as;

$$
\text { Scale inefficiency ratio }(\mathrm{SE})=\mathrm{Aq}_{\mathrm{c}} / \mathrm{Aq}_{\mathrm{v}}
$$

Firms, that a on the frontier have efficiency ratio equal 1, and firms below the frontier, have efficiency ratios less than 1. In the graph above, a firm producing at $q_{i}$ under constant returns to scale can reduce its inputs from $X_{i}$ to $X_{c}$ without reducing the output (input minimizing oriented efficiency). This behaviour can result in cost saving by reducing the resources by the amount equals the actual resources $\left(\mathrm{X}_{\mathrm{i}}\right)$ minus the minimum optimal resources $\left(\mathrm{X}_{\mathrm{c}}\right)$. On other hand, the firm producing at $\mathrm{q}_{\mathrm{i}}$ under constant return to scale can expand its output from $\mathrm{A}$ to $\mathrm{A}_{\mathrm{c}}$ and gain more output with the same inputs $\left(\mathrm{X}_{\mathrm{i}}\right)$ and hence output maximizing oriental efficiency. Thus at point $\mathrm{q}_{\mathrm{i}}$, the firm output inefficiency is $\mathrm{A} 0$ / $\mathrm{Ac} 0[0,1]$; whereas, under variable return to scale, its output inefficiency ratio is A0 /Av0 [0, 1].

The paper employs stochastic frontier analysis (SFA) to the overall technical efficiency of the banks. The frontier in the graph above represents the production frontiers of the stochastic frontier analysis. The method hypothesises a functional form of production and uses data to estimate the parameters of that function. This estimated function is then used to derive the estimate of efficiencies of the firms. The residual term of the stochastic frontier function is decomposed into normal error term and inefficiency term as presented below

$Y_{i t}=\alpha+B X_{i t}+D_{1}+D_{2}+V_{i t}-U_{i t}$

$Y=$ output vector

$X=$ input vector

$i=$ individual bank

$t=$ time period $t=1: 2000-2002, t=2: 2003-2005, t=3: 2006-2008$, and $t=4: 2009-2011$.

$\mathrm{D}_{1}=1$ : Saudi-owned banks.

$=0$ : otherwise

$\mathrm{D}_{2}=1$ : Islamic banks

$=0$ : otherwise

These dummies also capture the time-invariant bank type heterogeneity in the data.

$\mathrm{U}=$ Residual term that captures and represents the technical inefficiency of the bank. It's a distributed one sided error term with a non-zero mean. It's assumed to follow an exponential, or half-normal, or truncated-normal, distribution, so that estimated function in the above equation can represents a production possibilities frontier. These inefficiency residuals are computed using the LIMDEP software with the assumption of half-moved distribution of $\mathrm{U}_{\mathrm{i}}$.

$\mathrm{V}=$ Represents random noises, which are identically and independently distribution two sided error term with mean zero and constant variance.

The paper collects data for the period of 12 years, from 2000 to 2011 five measures of banking performance. These measures are total deposits, total operating income, total capital, administrative expenses and investments. Operating income is assured to be a final output measure, while capital and administrative expenses are considered to be input measures. The administrative expenses are a proxy for the labour inputs. Deposits and investments are considered to be intermediate output measures that are further used in producing some other output. Thus, the production function stated above is estimated these times. First, the banking sector produces deposits using its capital and labour (proxy here by administrative expenses) inputs. Estimating this function gives out the deposit efficiency scores. Second, the banking sector uses the mobilized deposits with administrative expenses as inputs to produce investments and estimating this function gives at the investment efficiency scores. Finally, the banking sector uses its investment and labour to produce operating income, and from this function, income efficiency scores are calculated. Twelve banks are selected out of 23 banks to represent the banking industry. These 12 banks have more than $90 \%$ of the industry's assets and deposits respectively, and hence they are approximately the industry. The data on the banking performance measures are collecting from the website of Saudi stock market. There are 36 observations of balanced 3-year period panel data. The 12 years observations 2000-2011 is broken into equal 3-years observation for the 12 banks. Two important benefits are derived from this setting: one benefit is to obtain balanced panel data; some banks under the study do not have straight 12 -year observations. The other benefits, is to make the individual effect random, and it 
can be captured by the $\mathrm{V}$ term, which is random error term in the equation. If the individual effect is not random but type specific, then dummies $D_{1}$ and $D_{2}$ shall tell what types of banks exist in the data. The time effect of 3 year period in the data is assumed constant and subsumed into the constant term of the equation.

\section{Results and Analysis}

The results are analysed in two stages. In the first stage, the paper analyses the estimated production functions (deposit production, investment production, and income production) to examine possible existence of bank types in the data and consistency of this type over time. Also at this stage, the significance of the assumed input measures is investigated. In the second stage, the paper examines these efficiency scores of banks. This is done by first ranking banks from 1 the top best to 12 the bottom worst. The ranks are broken into four categories excellent performers $(1,2$, $3)$, good performers $(4,5,6)$, fair performers $(7,8,9)$ and poor performers $(10,11,12)$. Than for each bank a percentage is calculated as how many times it falls under each category. The scores are also used to tell whether there exist specific bank types in the data, and the consistency of those banks types over time. The efficiency rankings and percentage times for each bank are presented in Table 3 in the appendix.

\subsection{Deposit Mobilization Function}

For deposits mobilization capital and labour (proxy by administrative expenses) are found by consistently relevant for the whole period of observation. Table 3 estimates indicate that increased capital and labour lead to increased deposit mobilization. The dummies for the bank types are fond relevant in observations $2000-2002$, and $2003-2005$. Whereas in the periods $2006-2008$, and $2009-2011$, the dummies cannot be included in the model due to their irrelevance and the acute skewness of the residuals, and thus the inefficiency scores cannot be correctly estimated. To further correct the skewness problem for the period 2009 - 2011, deposits and capital are divided by the administrative expenses, to approximate deposits per labour and capital per labour respectively. Where the bank types become relevant, it shows that the Saudi-owned banks and the Islamic banks are relatively poorer deposit mobilizers than the foreign non-Islamic banks, as illustrated by the graphs in appendices A and B.

Table 3. Stochastic frontier equation estimates, dependent variable: Deposits

\begin{tabular}{|c|c|c|c|c|}
\hline Variables & 2000-2002 & 2003-2005 & 2006-2008 & 2009-2011 \\
\hline Constant & $3.69(0.347)$ & $3.98 *(5)$ & $3 * * *(1.6)$ & $33.6(0)$ \\
\hline EX & $0.62 *(7.49)$ & $0.55 *(4.388)$ & $0.51 *(4.045)$ & ---- \\
\hline $\mathbf{C P}$ & $0.36 *(3.592)$ & $0.42 *(3.034)$ & $0.52 *(3.446)$ & $0.87 *(9.14)$ \\
\hline D1 & $-0.22 * *(-2.742)$ & $-0.14 * *(-1.943)$ & ---- & ---- \\
\hline D2 & $-0.23 * *(-2.406)$ & $-0.08(-0.828)$ & ---- & ---- \\
\hline $\begin{array}{r}\mathrm{EX}=\mathrm{adm} \\
\mathrm{CP}=\text { bank } \\
\mathrm{D} 1=1: \mathrm{Sa} \\
\mathrm{D} 2=1 \text { : Isl } \\
\text { Values out } \\
* \\
* \\
*\end{array}$ & $\begin{array}{l}\text { ive expenses (use } \\
\text { vned banks, and = } \\
\text { anks, and = } 0 \text { : oth } \\
\text { e bracket are the c } \\
\text { ficant at } 1 \% \\
\text { hificant at } 5 \% \\
\text { gnificant at } 10 \%\end{array}$ & $\begin{array}{l}\text { ere to proxy labour } \\
\text { therwise } \\
\text { vise } \\
\text { fficients and their c }\end{array}$ & sponding T-sta & in the bracket \\
\hline
\end{tabular}

\subsection{Investment Generation}

For the period 200-2002, Saudi banking sector is highly heterogeneous, Saudi-owned banks perform better in investment generation than non-Saudi-owned banks, and the Islamic banks generate more investment than non-islamic banks. Thus, the lowest investment generator in this period is the foreign non-islamic banks. The banking sectors rely largely on deposits to generate investment as indicated by the estimates in Table 4. Deposits remain the relevant source of investment for the rest of the period. The banking type refuses to fade away with time as in the period 2003-2005, the Saudi-owned banks appear to be the only banks making headways in investment, while in the period 2009-2011, the Islamic banks seem to be reducing their investments. This finding is clearly discernible in the appendices A and B. 
Table 4. Stochastic frontier equation estimates, dependent variable: Investment

\begin{tabular}{|c|c|c|c|c|}
\hline Variables & 2000-2002 & 2003-2005 & 2006-2008 & 2009-2011 \\
\hline Constant & $-8.42 *(-8.149)$ & $-8.917(-0.273)$ & ---- & $-1.522 * * *(-1.814)$ \\
\hline DP & $1.428 *(9.547)$ & $1.475 *(5.745)$ & $0.606(1.162)$ & $0.469 *(6.687)$ \\
\hline $\mathbf{E X}$ & $0.036(0.271)$ & $-0.024(-0.102)$ & $0.482 * * *(1.885)$ & $0.726 *(8.578)$ \\
\hline D1 & $0.334 *(4.253)$ & $0.21 * * *(1.82)$ & ---- & $0.024(0.218)$ \\
\hline D2 & $0.291 * *(2.999)$ & $0.248 * * *(1.625)$ & ---- & $-0.681 *(-5.657)$ \\
\hline \multicolumn{5}{|c|}{$\begin{array}{l}\mathrm{EX}=\text { administrative expenses (used here to proxy labour inputs) } \\
\mathrm{DP}=\text { bank deposits } \\
\mathrm{D} 1=1 \text { : Saudi owned banks, and }=0 \text { : otherwise } \\
\mathrm{D} 2=1 \text { : Islamic banks, and }=0 \text { : otherwise } \\
\text { Values outside the bracket are the coefficients and their corresponding T-statistics are in the bracket. } \\
\quad *=\text { significant at } 1 \% \\
\quad * *=\text { significant at } 5 \% \\
\quad * * * \text { - }\end{array}$} \\
\hline
\end{tabular}

\subsection{Income Generation}

As Table 5 illustrates the investment and labour appear to be positive relevant explanatory variables for the variations in the banking sector income throughout the period. The bank type surfaces in the periods 2000-2002, and 2009-2011. In the period 2000-2002, the Saudi-owned banks generate lower income than the rest, and in the period 2009-2011, the Islamic banks appear to generate higher income than the rest.

Table 5. Stochastic frontier equation estimates, dependent variable: Income

\begin{tabular}{lllll}
\hline Variables & $\mathbf{2 0 0 0 - 2 0 0 2}$ & $\mathbf{2 0 0 3 - 2 0 0 5}$ & $\mathbf{2 0 0 6 - 2 0 0 8}$ & $\mathbf{2 0 0 9 - 2 0 1 1}$ \\
\hline Constant & $0.045(0.124)$ & $0.546(0.054)$ & $0.071(0.004)$ & $1.76(0.108)$ \\
\hline IN & $0.514 *(8.86)$ & $0.224 * *(2.88)$ & $0.086(1.141)$ & $0.702 *(5.088)$ \\
\hline EX & $0.435^{*}(5.44)$ & $0.772 *(6.86)$ & $0.981 *(8.024)$ & $0.111(0.64)$ \\
\hline D1 & $-0.097 * *(-2.022)$ & $-0.082(-1.17)$ & $-0.017(-0.126)$ & $-0.104(-0.842)$ \\
\hline D2 & $0.039(0.691)$ & $0.18 * *(2.03)$ & $-0.151(-0.87)$ & $0.544 *(2.83)$ \\
\hline EX = administrative expenses (used here to proxy labour inputs) & \\
IN = bank investments & & \\
D1 = 1: Saudi owned banks, and =0: otherwise \\
D2 = 1: Islamic banks, and = 0: otherwise \\
Values outside the bracket are the coefficients and their corresponding T-statistics are in the bracket. \\
$\begin{array}{l}*=\text { significant at 1\% } \\
* *=\text { significant at } 5 \% \\
* * *=\text { significant at 10\% }\end{array}$
\end{tabular}

From this analysis, it can be inferred that the assumed relationships, between the output and input measures are confirmed by the data. The other inference is that in terms of deposit mobilization, the banks seem to be highly homogenous. This could be a result of indifference of bank customers, particularly the depositors. That is they do not place their deposits in a bank because it's a Saudi-owned, or Saudi-foreign-owned, or Islamic, bank. The indifference of the depositors could be the result of fixed deposits interest rate paid across the banks. This rate is determined by the SAMA, thus it's not included in the deposit production function as its same for all the banks. This also raises a question for further research, and that is do Saudi banks customers make their bank choice based on bank type? Or do they pool them together as non-differentiated bank?

\subsection{Deposit Efficiency}

The top performers in efficiently mobilizing deposits are Banque Saudi Franci (BSF) followed by Arab national bank, while Saudi investment bank and Alrajhi bank come in as third best performers. The good performers are Saudi Hollandi Bank, while the rest of banks are fair performers, no bank performed poorly in deposit mobilization. In 
terms of bank type, Saudi-foreign-owned banks, top the list of excellent performers, followed by Saudi-owned banks, and then an Islamic bank. The next efficiency score will tell whether this ranking could be sustained.

\subsection{Investment Efficiency}

Top performers in investment generation are Banque Saudi Franci, followed by Saudi Hollandi and then Saudi investment bank. The Banque Saudi Franci has maintained its top position as the best bank in mobilizing deposits and the best bank in transforming those deposits into investment throughout the whole period 2000 to 2011 . The Saudi Hollandi bank has improved its position from a good bank in deposit mobilization to the second best bank in transforming deposits into investments. The third best bank is the Saudi investment bank. The good investment performers are Saudi British Bank followed by Arab national bank and bank Al-Bilad; whereas, the fair and poor investment performers are Arab national bank followed by Riyadh Bank and Bank Aljazeera. The top bank type is a Saudi-foreign bank, followed by Saudi-owned bank type. The good bank types in term of investment are again Saudi-foreign owned banks, followed by Saudi-owned banks and an Islamic bank. Whereas the fair and poor bank types in terms of investment are Saudi-owned banks and Islamic banks. This is a disappointment for Islamic banks, which are supposed to be investment banks in nature as Islamic banking and finance require most financing and investment contracts to have real underlining assets or an exchange of money with commodity.

\subsection{Income Efficiency}

Alrajhi bank and SAMBA tied as the top income performers. They are the benchmarks in transforming investment into income. The good banks are Banque Saudi Franci followed by Riyadh Bank, while the fair and poor performers in terms of income efficiency are SABB followed by Arab national bank and Bank Aljazeera. The Saudi-foreign-owned bank and Islamic banks appears top performers in income efficiency.

The Saudi-foreign-owned banks are overall best banks, the other bank types of Saudi-owned and Islamic banks have seen overlapping ranking throughout the period. The Banque Saudi Franci is a benchmark for the other banks to emulate its best practices, while bank Aljazeera, Riyad Bank and Arab national bank need to increase their efforts to catch up with the rest. These findings conforms the conclusion rich at by Alkhathlan et al (2010). Alrajhi bank and SAMBA can do better than their current performance to improve their deposit mobilization and investment efficiency. The Islamic banks have performed disappointedly in their own area of speciality which is investment.

\section{Conclusions and Implications}

The findings of this paper fall under three categories which are bank density, stochastic production frontier, and efficiency scores and rankings. The bank density findings show that Saudi economy is substantially less dense compared to some advanced economies. The bank branches are not fast increasing in numbers. The bank density for most Saudi cities in 2011 does not significantly differ from what it was in 2006. Two things could be responsible for this low bank density; one is the increasing population particularly the foreign influx, which could counter balance the bank branch expansion. The other factor is the increased reliance of the Saudi banks on machine, telephone and electronic banking. Most bank services are increasingly delivered by these three media at relatively lower costs than the physical branches. The findings from the estimated stochastic production functions show that bank capital and labour are significant relevant factors for deposit mobilization. The deposit interest rate does not influence the deposit mobilization, as the banks take the deposit interest as given from SAMA and they cannot vary it on their own to attract deposits. Furthermore, the bank customers do not place their deposits in the banks as a function of interest rates which are culturally abhorred in Saudi Arabia. Thus, bank type does not matter in deposit mobilization. The deposits are found to significantly influence how much investment a bank can generate. Similarly bank investments are important source of income for the banks. The efficiency findings show significant disparities among the bank performances. A benchmark bank is found to be Banque Saudi Franci, which has been able to maintain a robust consistent top performance throughout the period 2000-201, and it is Saudi-foreign owned bank. On the three output efficiency scores of deposit, investment and income, it comes on the top in deposit efficiency, and investment efficiency and a good performer in income efficiency. An organizational study of this bank could yield a manual of best practises to be emulated by the other banks. Bank Alrajhi and SAMBA are the top income performers. The other banks have shown fluctuating pattern of behaviour from poor performance to good performance over the period of study.

\section{Acknowledgement}

The researchers would like to thank the Deanship of Scientific Research at King Saud University represented by the Research Centre at CBA for supporting this research. 


\section{References}

AlKhathlan, K., \& Malik, S. A. (2010). Are Saudi Banks Efficient? Evidence Using Data Envelopment Analysis (DEA). International Journal of Economics and Finance, 2, 53-58. http://dx.doi.org/10.5539/ijef.v2n2p53

Avkiran, N. K. (2011). Association of DEA super-efficiency estimates with financial ratios: Investigating the case for Chinese banks. Omega, 39, 323-334. http://dx.doi.org/10.1016/j.omega.2010.08.001

Barros, C. P., Chen, Z., Liang, Q. B., \& Peypoch, N. (2011). Technical efficiency in the Chinese banking sector. Economic Modelling, 28, 2083-2089. http://dx.doi.org/10.1016/j.econmod.2011.04.003

Censuses Statistics. (2011). Central Department of Statistics, Kingdom of Saudi Arabia. Retrieved from http://www.cdsi.gov.sa

Chortareas, G. E., Girardone, C., \& Ventouri, A. (2012). Financial freedom and bank efficiency: Evidence from the European Union. Journal of Banking \& Finance. http://dx.doi.org/10.1016/j.jbankfin.2012.11.015

Drake, L., \& Hall, M. J. B. (2003). Efficiency in Japanese banking: An empirical analysis. Journal of Banking \& Finance, 27, 891-917. http://dx.doi.org/10.1016/S0378-4266(02)00240-6

Economist. (2005). Bank Density. Retrieved from http://www.economist.com/node/5253146

Frimpong J. M. (2010). Investigating Efficiency of Ghana Banks: A Non Parametric Approach. American Journal of Scientific Research, 7, 64-76. Retrieved from http://www.eurojournals.com/ajsr_7_06.pdf

Hadi, A., \& Saad, M. (2010). An Analysis on the Efficiency of the Malaysian Islamic Banking Industry: Domestic vs. Foreign. International association for Islamic economics Review of Islamic Economics, 14, $27-47$.

Matousek, R., \& Taci, A. (2004). Efficiency in Banking: Empirical Evidence from the Czech Republic. Economics of Planning, 37, 225-244. http://dx.doi.org/10.1007/s10644-005-5059-4

Matthews, K., \& Zhang, N. (2010). Bank productivity in China 1997-2007: Measurement and convergence. China Economic Review, 21, 617-628. http://dx.doi.org/10.1016/j.chieco.2010.06.004

Maudos, J., \& Pastor J. M. (1999). Cost and profit efficiency in banking: an international comparison of Europe, Japan and USA. Instituto Valenciano de Investigaciones Económicas (IVIE); c/ Guardia civil 22, Esc 2, $1^{\text {a; }}$ Valencia-46020- (SPAIN) 1999. http://dx.doi.org/10.1080/135048501750237829

Mokhtar, H. S. A., Abdullah, N., \& Alhabshi, S. M. (2008). Efficiency and Competition of Islamic Banking in Malaysia. Humanomics, 24, 28-48. http://dx.doi.org/10.1108/08288660810851450

Olson, D., \& Zoubi T. A. (2011). Efficiency and bank profitability in MENA countries. Emerging Markets Review, 12, 94-110. http://dx.doi.org/10.1016/j.ememar.2011.02.003

Rosly, S.A., \& Abu Bakar, M. A. (2003). Performance of Islamic and mainstream banks in Malaysia. International Journal of Social Economics, 30, 1249-1265. http://dx.doi.org/10.1108/03068290310500652

Said, A. (2012a). Comparing the Change in Efficiency of the Western and Islamic Banking Systems. Journal of Money, Investment and Banking, 23, 149-180. Retrieved from http://ssrn.com/abstract=2028397

Said, A. (2012b). Efficiency in Islamic Banking during a Financial Crisis-an Empirical Analysis of Forty-Seven Banks. Journal of Applied Finance \& Banking, 2, 163-197. Retrieved from http://ssrn.com/abstract=2084626

SAMA. (2011). Annual Report, Saudi Arabian Monetary agency. Retrieved from http:/www.sama.gov.sa/sites/samaen/ReportsStatistics/ReportsStatisticsLib/Annual\%20Report-english-48.xlsx

Shahid, H., Rehman, R., Niazi, G. S. K., \& Raoof, A. (2010). Efficiencies Comparison of Islamic and Conventional Banks of Pakistan. International Research Journal of Finance and Economics, 49, 24-42.

Sufian, F. (2007). The efficiency of Islamic banking industry in Malaysia Foreign vs. domestic banks. Humanomics, 23, 174-192. http://dx.doi.org/10.1108/08288660710779399

Sun, L., \& Chang, T. P. (2011). A comprehensive analysis of the effects of risk measures on bank efficiency: Evidence from emerging Asian countries. Journal of Banking \& Finance, 35, 1727-1735. http://dx.doi.org/10.1016/j.jbankfin.2010.11.017

Wu, C.R., Tsai, H.Y., \& Wang, Y.M. (2008). Efficiency Comparison of Operational and Profitability: A Case of Hong Kong Commercial Banks. Journal of Social Sciences, 4, 280-287. http://dx.doi.org/10.3844/jssp.2008.280.287

Xuan, Huy, \& Dang, Hoan. (2010). Evaluation of input efficiency for catfish farms in Mekong River Delta, Vietnam, Fisheries Training Programme, the United Nations University. Retrieved from Icelandhttp://www.unuftp.is/static/fellows/document/huy_2010.pdf 


\section{Appendices}

Appendix A. Inefficiency scores and bank ownership types

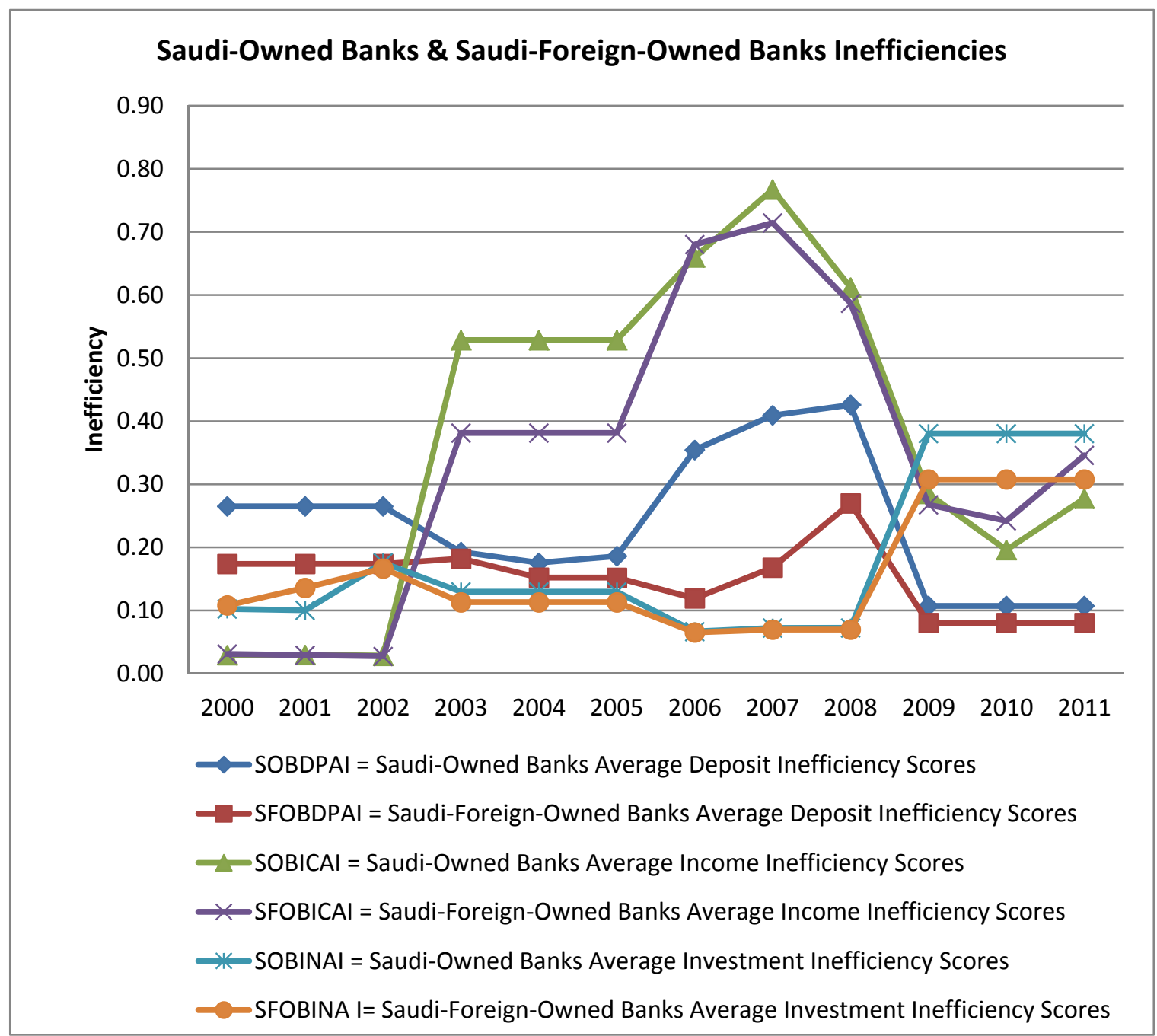


Appendix B. Inefficiency scores: Islamic banks versus conventional banks

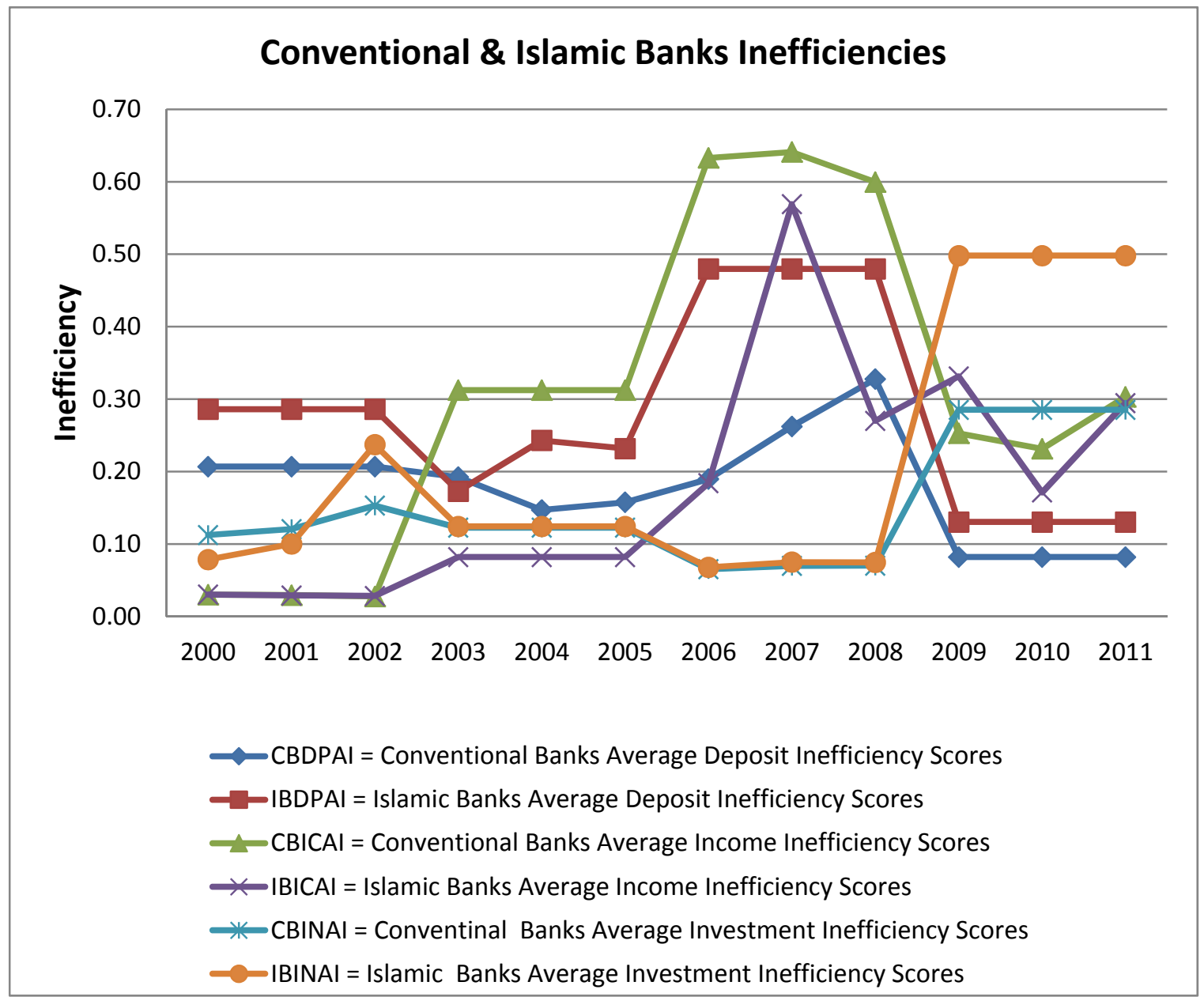

